\title{
DEVELOPING ESP READING MATERIALS FOR THE \\ ELEVENTH YEAR DRESSMAKING STUDENTS OF \\ VOCATIONAL HIGH SCHOOL
}

\author{
*Rosy Maya Deli Samosir \\ **Lidiman S M Sinaga \\ **Tiarnita M S Siregar
}

\begin{abstract}
Samosir, Deli, Maya, Rosy. Registration Number: 2123321070. Developing ESP Reading Materials for the Eleventh Year Dressmaking Students Vocational High School. A Thesis. English Educational Program, State University of Medan, 2016
\end{abstract}

The Objective of this research were: (1) To develop ERM to meet the needs of second grade of dressmaking students at SMKN 10 Medan, (2) To Design ERM which is suitable to the needs of second grade of dressmaking students at SMKN 10 Medan. The subjects were the eleventh year students of dressmaking department at SMKN 10 Medan. The study was a Research and Development ( R \& D) study which is adapted from Borg and Gall (1983). This research were conducted by six phases, they are, Gathering information and data, Analyzing data, Designing new reading materials, Validating new reading materials, Revising new reading materials, Revised-developing reading materials. The Instruments for collecting the data were 30 questionarries need analysis and interview students, teacher and practitioner. The results from the data were the students need authentic material which related and appropriate to their need in order they can understand English well. The developed materials were validated by two experts, one is a lecture and the other is a teacher. The validator scored 4 creteria. The research findings showed that the developed materials were appropriate to be implemented. The average score of validation was 4,72 (lecture score) and 4,75 (teacher score). Based on the results of the study, conclusion and suggestions are directed to the teachers and institution who are teaching in SMKN 10 Medan generally to create and to develop the materials based on students need.

Key words: English Reading Materials, Vocational High School Students, English for Specific Purpose 
*Graduate Status

***Lecturer Status

\section{INTRODUCTION}

\section{Background of the Study}

In the era globalization English has become a language that should be well mastered by many people in the context of job market especially in dressmaking field. Many sources of information and knowledge are written in English especially from internet source, creative design book. So, English is not a modern language in this era, but it is a necessary language to get better life and better position. To be a successful fashion designer, the students have to have wide understanding about variety of core principles such as methods of designing, the creative technique in dressmaking and color principle strengthten a designer's message and how to envolve their own vision (Faerm,2010). They need English to increase their skill in the future especially in English materials (procedure text in dressmaking) so they can access the better, innovative, creative information ways in dressmaking and comprehend the way a dress is made in written or spoken.

Education is a formal process that is expected to improve and advance students' skill which is needed by them in fulfilling their daily needs of life in the future; at least, education can be a media for students to increase their quality in term of knowledge. By having it, students are expected to be experts of the subjects that they focus on, or at least, they can get benefit of having gotten the education by an implementation of what they have in education. 
General English usually offers a judicious blend of different language skills and the topics that are chosen from all range of sources, and based on the selection of content more on students' interest and engagement rather than an early identifiable students' need. In contrast English for Specific Purposes (ESP) has closely identified goals for learning (Kariman \& Nababan, 2006).

ESP is seen as an approach, not a product, which means that no special form of language is taught, but it can be identified as typical of a typical of a particular context of use. It is meant that the learners would likely meet the target situation (Hutchinson and Waters, 1989). ESP is not different from any other language teaching; that is based on the principle of effective and efficient learning. ESP course are providing the learners with competence of us English for Specific Fields of knowledge at the advanced level. ESP is generally based on needs of the students, which are aimed at specifying what are exactly the students' need in studying English.

Based on the writer's analysis of syllabus and teaching materials, particularly in the subject of English which are used by students of a particular SMK in Medan, the teaching materials are not related for any certain vocation. In their textbook "Buku Bahasa Inggris" published by Pusat Kurikulum dan Perbukuan, Balitbang, Kemendikbud, they are taught by using a text about how to make jasmine, how to make cheese toast, how to make pizza, and how to make Indonesian chicken satay and then they are asked to answer the question about that text. Actually they are not the relevant material for the students of dressmaking in vocational school. As vocational school is concerned with 
preparing students' ability in their major for working in the future, means that the students of Vocational School learn English for a specific purpose (ESP) that is related to their target job in the future. It is stated in the content standard of the national education standard board or Badan StandarNasional Pendidikan (2006:112), the purposes of English subject in Vocational School are: (1) mastering the basic knowledge and skill of English to support the students in achieving the competency of their expertise program; (2) applying their knowledge and skill of English to communicate in both spoken and written communication in intermediate level.

They learn English but their English is not aimed to acommodate their needs. Teacher just teach the reading materials which is applied in the textbook; teacher does not exist their own materials. That's why their felt into fulfill subject matter only. Based on this there is an assumption that they do not have yet English for Specific Purpose. 


\section{REVIEW OF LITERATURE}

It is really important to develop teaching materials for helping students in reaching the goal of a teaching and learning process. Developing teaching material is one of some ways that can be done by a teacher to make the learning process in the class more effective. Development of teaching materials is related to the analysis of what students need in that learning process through having some certain teaching materials, such as, necessity, lacks, and wants. There are two steps to develop these learning materials, a teacher has to follow the correct procedure of developing learning materials. There are two major steps to develop the learning materials. First, a teacher has to learn the learners needs and especially the syllabus, choose the item by one item from the syllabus one by one and then develop the materials. Second, s/he has to develop the learning materials according to the nature of the learning materials or make own materials and the principles as well as the procedure of developing the learning materials. The analysis of what students need from teaching materials is very crucial for teachers to know how a teaching-learning process should be done, including what teaching materials should be used. When students are taught by using teaching materials, particularly English materials, based on what they need in term of vocational purposes, it will be easier for them to reach the goal that teaching and learning process because of the fulfillness of their necessity about English to support their vocational purposes.

Developing teaching/learning materials for ESP is more demanded than that for general English because the availability of the ESP learning materials in public 
is very rare. Because of this, teachers of ESP develop their own specific materials for their own target language learners through the approach in approaches to course design in Hutchinson's book.

The research is conducted by using Research and Development Method ( R \& D), which is adapted from Borg and Gall (1985:775) in fulfilling the students' need in reading comprehension materials. This research is applied five main phases of development, they are namely: (1) analyzing existing syllabus, existing reading materials, and students' needs to identify problems, (2) reviewing the theory of principle of effective reading materials, (3) designing syllabus and reading materials, (4) validating new reading materials to the experts, and (5) revising new reading materials as suggested by expert. 


\section{RESEARCH METHODOLOGY AND FINDINGS}

\section{Methodology}

The research was conducted by using developmental research which is adapted from Borg and Gall (1983) in fulfilling the students' need in reading comprehension material. The data was served in the form of descriptive sentence. This research were conducted by following six phases of $R \& D$, they are: 1.) Gathering information and data, 2.) Analyzing data, 3.) Designing new reading materials, 4.) Validating new reading materials, 5.) Revising new reading materials, 6.) Revised-developing reading materials (final product).

\section{Techniques of Data Analysis}

The data were collected through questionnaires and interviews. The questionnaires were administered to get the data of the students and the teachers, while the interviews were administered to support the data on the students' of learning English especially the vocabulary mastery. The data identified the main variables such as: Target need, Weakness, and Needs analysis of the Vocational High School of Dressmaking Department. The data were used to plan syllabus and materials and the data are analyzed through:

1. Needs analysis by using questionnaries and interviews. Questionnaires were administered to the students to get the related data. Interviews were also administered to the teacher to support the questionnaries, then, the data were tabulated in order to obtain the best solution in terms of 
preparing what material designs were appropriated for the vocational high school students at second grade.

2. Analyzing the syllabus and the existing materials. In this stage the researcher are considered between the basic competence as well as the book, before developing the materials.

\section{Findings}

After analyzing all data, the findings of this study could be seen below.

1. Gathering information and Data: Firstly, the reading materials in English book were not suitable for their learning needs (dressmaking student). Secondly, there should be materials development which fulfilled their needs. Furthermore, the detail information was needed to develop the materials based on students' need. Then questionnaire was distributed to 30 respondents of grade XI students of SMK NEGERI 10 Medan, particularly in Dressmaking Department and interview session was administered to English teachers and headmaster.

2. Analyzing data: Based on the questionnaires and interview given to the students, it was obvious that students need English focused on English for Dressmaking based on their major, because they think for their future job after graduating from their school and be creative in designing the clothe, dress, and skirt. The data also related to the students' answer according to their difficulties in learning English subject. Most of them had difficulties in understanding reading materials. Based on interview with the English subject teacher, students and also practitioner, obviously the teacher and the practitioner said that the students were 
so difficult to catch up most of the reading texts because the text were so general in the context, not have corellation with their major. The result data from the questionnaires, reading skill, it was found that $53 \%$ of the students less to understood the reading texts and only $47 \%$ who can be understood the text well. There were some reasons of the case. First, the students did not understand the vocabulary of the text because the vocabulary is not relevant with their major (50 $\%)$. Second, the students did not understand the structure of the text (20\%). The last, the students had difficulties to understand and conclude the content of the text $(30 \%)$. The practitioner said that the students should be given reading materials that can support their expertise major.

3. Designing New Reading Materials: Based on need analysis, it was got that student of vocational school- Dressmaking need teaching materials which are appropriate for their vocation in term of topic, vocabulary, kind of text, and complexity of language level. The appropriate materials for dressmaking students are: How to Make Simple Skirt, How to Sew Falling for Florals Skirt, How to Sew Versatile Little Black Dress, and How to Make Draped Maxi Dress. Those topic changed the unrelated topic in dressmaking students.

4. Validating by Experts: The developed materials were validated by two experts, one was validated by Dra. Masitowarni Siregar, M. Ed, as a lecturer and the other was validated by Dra. Elita Ginting, as an English Teacher in the school.

5. Revising Reading Materials: English teacher suggested to repair the wrong position of capitalization in the sentence. Then, she suggested to change punctuation (" and ") be (cm and inch). Furthermore, she did not find any false 
information on developed English reading materials. Meanwhile, lecture suggested to put the picture on each step in the procedure text of simple skirt.

6. Revised- Developing Reading Materials (Final Product): There were four developed reading materials that related to their department as dressmaking department. The procedure text were the procedure how to make simple skirt, how to sew falling for florals skirt, how to sew versatile little black dress, and how to make draped maxi dress. Based on the applied topic, the validator give the score on the developed materials. English teacher categorized the reading materials as the relevant studies by averange score 4,75 . She scored the reading materials through 4 criteria such as Idea, Content, Punctuation and Performance. Second, Lecture, she also catergorized the developed reading materials as the relevant materials by averange score 4,72. She scored teh developed reading materials through 4 criteria also such as Linguistic, Process, Product and content, and Layout. 


\section{CONCLUSION AND SUGGESTIONS}

\section{Conclusion}

After analyzing the data, the conclusion were drawn as the following:

1. The existing materials are too general for the students of dressmaking. They were taught by culinary reading materials such as " how to make orange juice", " how to make satay", and " how to make pizza". The existing reading materials are not related to students' need. The procedure text about " how to make skirt", "how to make long pants", how to make dress" are appropriate to the students' needs.

2. Theory of ESP should be considered in deciding the appropriate reading materials to the students of dressmaking. The content of reading materials should be related to dressmaking major.

3. New reading materials should be developed through 6 phases, they were 1) Gathering information and data, 2) Analyzing data, 3) Designing materials based on the needs analysis, 4) Validating the new reading materials by experts (English subject teacher and English lecturer), 5) Revising the new reading materials based on experts' suggestions, and 6) Final product.

4. New English reading materials were validated by two experts, one is a lecture, and the one is a teacher. The experts validated new English reading materials through questionnaire. The questionnaire for lecture consists of the dimensions of linguistic features, processes, contents, and layout. Neverthless, the questionaire for teacher consists of the dimensions of idea, content, punctuation, 
and performance. The result of questionarries shows that the new English reading materials are relevant to the dressmaking students in SMK NEGERI 10 Medan.

\section{Suggestions}

Based on the conclusion to the findings pointed above, the following suggestions are needed to be considered in conducting the related research.

1. For English teachers, they should not give the general English reading materials. Teacher should consider the students needs for the future. Teacher should taught the English reading materials that the contents are related to the students field.The contents of reading materials for students of dressmaking should be related to dressmaking.

2. For the Instution, they should encourage English teacher to identify students' need for learning English, and constructs the appropriate reading materials which accommodate the students' need. Appropriate reading materials make teaching-learning process run smoothly and effectively.

3. For Other Researcher, they should find many references to support in developing reading materials. The open questions of questionnaire should be considered to give the students' chance to deliver their wants in new reading material. 


\section{REFERENCES}

Alderson, J. Charles. (2000). Assesing Reading. Cambridge: Cambridge Univeristy

Anderson, Mark and Kathy Anderson. 2003. Text types in English 2. Sidney: Mac Millan Education Australia Pty Ltd

Benavent, G.T. \& Penamaria, S.S. 2011. Use of Authentic Materials in the ESP Classroom. Encuentro, Vol. 20, pp. 89-94

BSNP. 2006. Standar Kompetensi dan Kompetensi Dasar SMK/MAK. Jakarta: Badan Standar Nasional Pendidikan.

Gebhard, J.G. 1996. Teaching English as foreign language: A teacher selfdevelopment and methodology guide. Ann Arbor: The Univeristy of Michigan Press

Guariento, W. \& Morley, J. 2001. Text and task authencity in the EFL classroom in ELT Journal 55(4), pp 347-353

$\mathrm{Hu}$, R. 2009. English Reading Instruction in Elementary Schools in China. The Reading Matrix, 9 (2), pp 150-16

Hyland Ken. 2002. Teaching and Researching Writing. London: Person Publication.

Kariman, T.M. \& Nababan, T. (2006). Key Issues In ESP Materials Development for Chemical Engineering Students. Pertemuan Linguistik Utara 5 Medan.

Kelly, Gabrieella,2004, English for Theology. Seri 1. South Australia: ATF Press

Kementerian Pendidikan dan Kebudayaan. 2014. Bahasa Inggris /Kementerian Pendidikan dan Kebudayaan. Jakarta: Kementerian Pendidikan dan Kebudayaan

Koamesakh, A. 2011. English Reading Material Development for Student of Theology. Medan: State University of Medan

Marand, E. S. 2011. Adoption, Adaptation, and Development of Language Instructional Units. European Journal of Social Sciences, 22 (4): 550 
Matondang, M. K. D. 2011. Developing ESP Materials for Students of Law Faculty. State University of Medan: English Applied Linguistics StudyProgram

Nuttall, C. 1996. Teaching reading skills in a foreign language (New Edition) Oxford, Heinemann

Perfetti, C.A, Landi, N., \& Oakhill, J. 2004. The Acquisition of Reading Comprehension Skill. Oxford: Blackwell

Robinson, P. (1991). In Dudley-Evans, T.\& St.John, M. 1998. Developments in ESP: A multidisciplinary approach. Cambridge: CambridgeUniversity Press.

Schonell, Fred J. 2006. The Psychology and Teaching of Reading. London: Oliver and Boyd Ltd.

Shepherd, S. 2004. Using Authentic Materials. In teachingenglish.org.uk. Accessed on March 26th, 2016

Siregar, Hasnah. 2013. English reading materials for students of accounting in Vocational School through authenticity-centered approach. Medan: State University of Medan

Widdowson, R. 2006. The Beginner's Guide to Mind, Body \& Spirit. New York: New Line Books

http://www.k12reader.com. Accessed on March $28^{\text {th }}, 2016$

http://www.nclrc.org/essentials/reading/reindex.htm.Accessed on March $28^{\text {th }} 2016$

http://www.amazon.com. Accessed on June $12^{\text {th }}, 2016$

http://sastra.um.ac.id. Accessed on March $28^{\text {th }}, 2016$

http://www.allfreesewing.com. Accessed on July $27^{\text {th }}, 2016$

http://www. thesewingloftblog.com. Accessed on July $27^{\text {th }}, 2016$

http://www. sewpetitegal.com. Accessed on July 30 ${ }^{\text {th }}, 2016$ 